\title{
Analisis Pengelolaan Keuangan Daerah Pemerintah Daerah Kabupaten Kepulauan Talaud
}

\author{
MARLIN PAREDA ${ }^{1}$, JULLIE J. SONDAKH ${ }^{2}$, VENTJE ILAT ${ }^{3}$ \\ ${ }^{1,2,3}$ Program Magister Akutansi, Fakultas Ekonomi dan Bisnis Universitas Sam Ratulangi \\ email: alin_pareda@yahoo.com ${ }^{1}$, julliesondakh@yahoo.com ${ }^{2}$, ventje_ilat@unsrat.ac.id ${ }^{3}$
}

\begin{abstract}
The Regional Budget (APBD) is established to improve the capacity of local government in providing services to the community. The Regional Budget (APBD) is an annual form of the Regional Long-Term Development Plan (RPJPD) as well as the Regional Medium-Term Development Plan (RPJMD) are set up in accordance to the vision and mission of the regional head. The Regional Budget (APBD) is prepared by the Regional Government, discussed and approved by the Regional House of Representatives (DPRD). It is thus becoming a legal product, in form of Regional Regulation (Perda) and must be followed by all institutions in the region. This study aims to analyze the financial management of the Regional Government of Talaud Islands Regency. This is a qualitative exploratory research. Data were obtained through in-depth interviews and documentation studies. Key informants are determined by purposive sampling to obtain accurate information. Interviews were conducted by using semi-structured in-depth interviews. The triangulation method was used in order to test the validity or credibility of data and data sources. Results showed that in the process of local government financial management from planning and budgeting and implementation process has been referring to Permendagri No. 13 of 2006 on Guidelines for Management of regional finances but there are still obstacles that are 1) Bureaucratic Structure, (2) Resources, (3) Communication, (4) Disposition or Attitude, (5) Budget Limitations.
\end{abstract}

Keywords: Regional Financial Management, Obstacles.

\begin{abstract}
Abstrak. Dalam meningkatkan kapasitas pemerintah daerah dalam memberikan pelayanan kepada masyarakat maka disusunlah Anggaran Pendapatan dan Belanja Daerah (APBD). Anggaran Pendapatan dan Belanja Daerah (APBD) merupakan wujud tahunan dari Rencana Pembangunan Jangka Panjang Daerah (RPJPD) serta Rencana Pembangunan Jangka Menengah Daerah (RPJMD) yang dibuat dari visi dan misi kepala daerah. Anggaran Pendapatan dan Belanja Daerah (APBD) dipersiapkan oleh Pemerintah Daerah, dibahas dan disetujui oleh Dewan Perwakilan Rakyat Daerah (DPRD) sehingga pada akhirnya menjadi produk hukum berupa Peraturan Daerah (Perda) yang harus diikuti oleh segenap lembaga di daerah. Penelitian ini bertujuan menganalisis pengelolaan keuangan daerah Pemerintah Daerah Kabupaten Kepulauan Talaud. Metode penelitian menggunakan kualitatif dengan pendekatan eksploratif. Data diperoleh melalui teknik wawancara mendalam dan studi dokumentasi. Informan kunci ditentukan secara purposive sampling untuk mendapatkan hasil informasi yang tepat dan akurat. Wawancara menggunakan In-depth interview jenis semi terstruktur. Metode triangulasi digunakan dalam pengujian validitas atau kredibilitas data dan sumber data. Hasil penelitian menunjukkan bahwa dalam proses pengelolaan keuangan daerah pemerintah daerah mulai dari proses perencanaan dan penganggaran dan pelaksanaan dilaksanakan berdasarkan ketentuan dalam Peraturan Menteri Dalam Negeri Nomor 13 Tahun 2006 tentang Pedoman Pengelolaan Keuangan Daerah belum optimal masih terdapat hambatan-hambatan yaitu 1) Struktur Birokrasi, (2) Sumber Daya, (3) Komunikasi, (4) Disposisi atau Sikap, (5) Keterbatasan Anggaran.
\end{abstract}

Kata Kunci: Pengelolaan Keuangan Daerah, Hambatan.

\section{Pendahuluan}

Desentralisasi merupakan penyerahan urusan pemerintahan oleh Pemerintah Pusat kepada daerah otonom sebagaimana yang diatur dalam Undang-Undang Nomor 9 Tahun 2015 tentang Pemerintahan Daerah. Asas otonomi memberikan keleluasan kepada kepala daerah baik di Provinsi, Kabupaten maupun Kota untuk mengelola sumber daya yang dimiliki supaya tujuan pemerintahan tercapai. Penjelasan umum Undang-Undang Nomor 9 Tahun 2015 tentang Pemerintah Daerah menyebutkan pemberian otonomi kepada daerah diarahkan untuk mempercepat terwujudnya kesejahteraan masyarakat melalui peningkatan pelayanan, pemberdayaan dan peran serta masyarakat.

Dalam pemberian kewenangan yang luas bagi daerah untuk mengatur dan mengurus diri sendiri, pemerintah menata sistem pengelolaan keuangan untuk kelancaran pelayanan masyarakat dan juga untuk pembangunan yang berkelanjutan diantaranya melalui perubahan sistem pemerintahan dengan 
mengeluarkan (1) Undang-Undang Republik Indonesia Nomor 17 Tahun 2003 tentang Keuangan Negara, (2) Peraturaan Pemerintah Nomor 58 Tahun 2005 tentang Pengelolaan Keuangan Daerah, (3) Peraturan Pemerintah Nomor 8 Tahun 2006 tentang Pelaporan Keuangan dan Penilaian Kinerja, (4) Peraturan Menteri Dalam Negeri Nomor 13 Tahun 2006 tentang Pedoman Pengelolaan Keuangan Daerah, (5) Peraturan Menteri Dalam Negeri Nomor 59 Tahun 2007 sebagai perubahan pertama atas Peraturan Menteri Dalam Negeri Nomor 13 Tahun 2006 tentang Pedoman Pengelolaan Keuangan Daerah, (6) Peraturan Menteri Dalam Negeri Nomor 21 Tahun 2011 sebagai perubahan kedua atas Peraturan Menteri Dalam Negeri Nomor 13 Tahun 2006 tentang Pedoman Pengelolaan Keuangan Daerah.

Pengelolaan keuangan daerah merupakan sub sistem dari pengelolaan keuangan negara, pada dasarnya adalah bagian dari sistem keuangan negara dan merupakan elemen pokok dalam penyelenggaraan Pemerintah Daerah. Hubungan keuangan antara Pemerintah Pusat dan Daerah paling tidak mencakup: (1) pembagian kewenangan pendapatan (perpajakan), (2) sistem dan mekanisme untuk mengatasi ketimpangan horizontal dan, (3) sistem dan mekanisme untuk mengatasi ketimpangan vertikal. Pada sisi pengeluaran, diberikannya kewenangan fiskal kepada sebuah daerah otonom didasarkan kepada prinsip agar alokasi sumber daya lebih efektif dan efisien. Pemerintah Daerah yang lebih dekat ke masyarakat diasumsikan lebih tahu kebutuhan masyarakat dibandingkan dengan Pemerintah Pusat. Sehingga alokasi sumber daya yang dilakukan oleh Pemerintah Daerah (Pemda) akan lebih responsif dan menjawab kebutuhan masyarakat. Sedangkan pada sisi penerimaan, diberikannya kewenangan perpajakan kepada daerah dimaksudkan agar partisipasi masyarakat untuk mendanai pelayanan publik lebih tinggi karena masyarakat dapat merasakan langsung manfaat dari pembayaran pajak/retribusi tersebut.

Proses perencanaan anggaran merupakan salah satu langkah penting dalam pengelolaan anggaran. Sejak dua belas bulan sebelum tahun anggaran dimulai, proses perencanaan anggaran sudah mulai berjalan (BPKP, 2012). Perencanaan dapat diartikan sebagai suatu proses untuk menentukan tindakan masa depan yang tepat, melalui urutan pilihan, dengan memperhitungkan sumber daya yang tersedia. Dalam konteks perencanaan pembangunan pemerintah, maka penyusunannya berpedoman pada Undang-Undang Nomor 25 Tahun 2004 tentang Sistem Perencanaan Pembangunan Nasional. Sedangkan penganggaran dapat diartikan sebagai suatu proses untuk menyusun sebuah anggaran, dan Anggaran Pendapatan dan Belanja Daerah (APBD) dapat diartikan sebagai rencana keuangan tahunan Pemerintah Daerah (Pemda) yang dibahas dan disetujui bersama oleh Pemerintah Daerah (Pemda) dan Dewan Perwakilan Rakyat Daerah (DPRD), dan ditetapkan dengan Peraturan Daerah (Perda), (Mulyana, 2010:12).

Pelaksanaan anggaran merupakan tahapan pengelolaan keuangan yang harus dilaksanakan setelah proses perencanaan anggaran selesai. Pelaksanaan merupakan aktivitas atau usaha-usaha yang dilaksanakan untuk merealisasikan semua rencana dan kebijakan yang telah dirumuskan dan ditetapkan (BPKP, 2011). Pelaksanaan anggaran merupakan implementasi perencanaan anggaran yang telah disusun. Proses pelaksanaan anggaran meliputi persoalan-persoalan yang terjadi dalam internal satuan kerja, serta proses mekanisme pembayaran (pencairan anggaran).

Permasalahan yang terjadi di Pemerintah Kabupaten Kepulauan Talaud dalam proses pelaksanaan anggaran adalah penerbitan SK penunjukan/pergantian pejabat perbendaharaan, pengguna anggaran (PA), kuasa pengguna anggaran (KPA), pejabat pembuat komitmen (PPK) dan bendahara pengeluaran yang sering mengalami keterlambatan, petunjuk teknis yang sering mengalami keterlambatan dan anggaran kas yang telah disusun bergeser dari jadwal yang telah ditetapkan sehingga pelaksanaan anggaran menjadi terlambat. Sebagai gambaran selama periode tahun anggaran 2012-2015 pada pelaksanaan Anggaran Pendapatan dan Belanja Daerah (APBD) realisasi anggaran pemerintah daerah mencatat hampir setiap tahun anggaran ada dana yang tidak terealisasi di rekening kas daerah (idle money) yang berakibat hilangnya manfaat belanja, karena dana yang dialokasikan ternyata tidak semua dapat dimanfaatkan oleh pemerintah yang artinya ada dana yang menganggur (BPKP, 2011)

Menurut Peraturan Menteri Dalam Negeri Nomor 13 Tahun 2006 tentang Pedoman Pengelolaan Keuangan Daerah adalah keseluruhan kegiatan yang meliputi perencanaan, pelaksanaan, penatausahaan, pelaporan, pertanggungjawaban dan pengawasan keuangan daerah namun penulis hanya fokus pada proses perencanaan dan penganggaran dan Proses pelaksanaan Program/kegiatan karena dikatakan dengan adanya perencanaan yang baik maka pelaksanaan program/kegiatan akan baik berjalan baik sehingga penatausahaan, pelaporan dan pertanggungjawabnya pun akan baik 
mengikuti karena perencanaan dan penganggaran dan pelaksanaan adalah langkah awal dalam pengelolaan keuangan daerah dari fenomena diatas, pengelolaan keuangan daerah harusnya dikelola sesuai dengan program yang tertuang dalam Rencana Kerja Perangkat Daerah (RKPD) dan Anggaran Pendapatan dan Belanja Daerah (APBD) agar memberikan manfaat yang sesuai dengan kebutuhan dasar masyarakat. Akan tetapi hingga saat ini pelaksanaan pengelolaan di Kabupaten Kepulauan Talaud masih belum dilaksanakan sebagaimana yang telah direncanakan dalam dokumen perencanaan, mengakibatkan penyusunan program dan kegiatan Satuan Kerja Perangkat Daerah (SKPD) masih memiliki kelemahan-kelemahan bahkan ada program kegiatan yang dilaksanakan tidak sesuai dengan tugas dan fungsi Satuan Kerja Perangkat Daerah (SKPD) sehingga masih membutuhkan revisi saat pelaksanaan anggaran, yang berdampak pada realisasi anggaran belanja daerah pada pengelolaan keuangan daerah.

\section{Model Analisis}

Model analisis pada penelitian ini dimulai dengan telaah paradigma melalui kajian isu-isu empirik tentang perencanaan dan pengangaran, dan pelaksanaan dalam pengelolaan keuangan daerah, kemudian penulis menentukan topik Analisis Pengelolaan Keuangan Daerah Pemerintah Daerah Kabupaten Kepulauan Talaud. Langkah berikut adalah fokus penelitian yaitu pada proses perencanaan, dan penganggaran, dan proses pelaksanaan Anggaran Pendapatan dan Belanja Daerah sesuai dengan Peraturan Menteri Dalam Negeri Nomor 13 Tahun 2006 tentang Pedoman Pelaksanaan Pengelolaan Keuangan Daerah serta menganalisis hambatan-hambatan dalam pengelolaan keuangan daerah dan upaya-upaya yang dilakukan untuk mengatasi hambatan-hambatan yang ada. Untuk lebih jelas model analisis penelitian ini dapat dilihat pada Gambar 3.1 berikut.

\section{Gambar 3.1 Model Analisis}

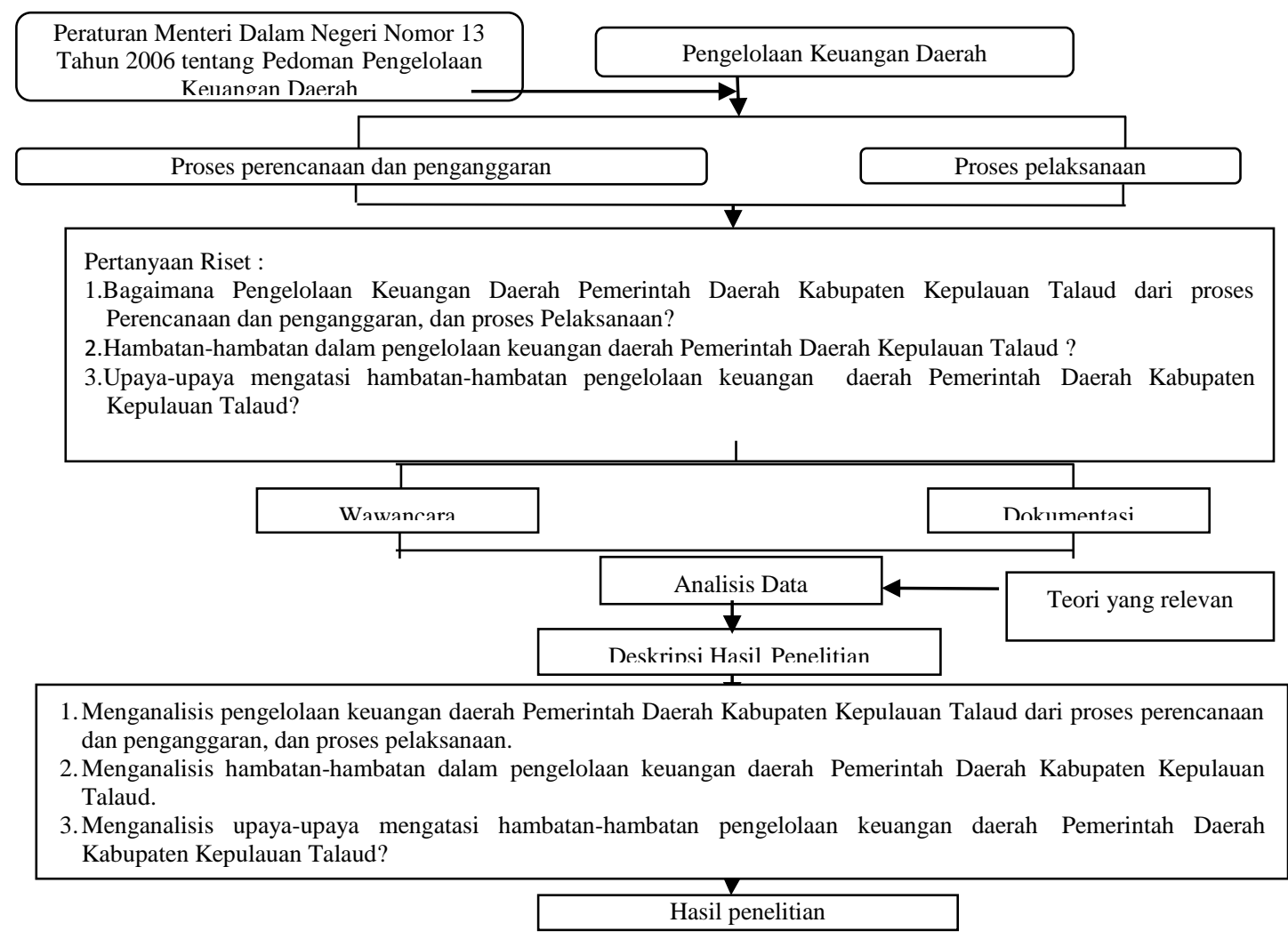

\section{Metode Penelitian}

Penelitian ini menggunakan metode penelitian kualitatif dengan pendekatan eksploratori (exploratory approach). Metode Penelitian kualitatif menurut Sugiyono (2015:1) sering disebut metode penelitian naturalistik karena penelitiannya dilakukan pada kondisi yang alamiah (natural setting). Metode kualitatif ini dipilih agar data yang diperoleh akan lebih lengkap, lebih mendalam, kredibel dan bermakna sehingga tujuan penelitian dapat dicapai. Eksploratori menurut Arikunto 
(2010:32) adalah metode penelitian yang bertujuan untuk menggali suatu informasi. Ibrahim (2015:61) menjelaskan bahwa pendekatan eksploratori dalam penelitian kualitatif adalah cara kerja penelitian yang dimaksudkan untuk menemukan lebih jauh dan mendalam terhadap kemungkinan-kemungkinan lain dari permasalahan yang diteliti. Dengan pendekatan eksploratori, penelitian tidak lagi sekedar menggambarkan atau melukiskan atau menjelaskan seperti apa adanya realitas yang dikaji sebagaimana pada metode deskriptif. Pendekatan eksploratori dalam penelitian ini berupaya menemukan informasi secara lebih lengkap, mendetail dan mendalam mengenai bagaimana pengelolaan keuangan daerah dari proses perencanaan dan penganggaran, dan proses pelaksanaan, hambatan-hambatan dalam pengelolaan keuangan daerah serta upaya-upaya mengatasi hambatanhambatan pengelolaan keuangan daerah Pemerintah Daerah Kabupaten Kepulauan Talaud.

a).Wawancara mendalam (In-depth Interview).

Menurut Esterberg dalam Sugiyono (2014), mendefinisikan wawancara adalah pertemuan dua orang untuk bertukar informasi dan ide melalui tanya jawab, sehingga dapat dikontruksikan makna dalam suatu topik tertentu. Selain itu memudahkan dalam menjaring informasi yang menjadi fokus penelitian. Wawancara dapat digunakan untuk menggali lebih dalam dari data yang diperoleh dari observasi.

Dalam penelitian ini wawancara digunakan untuk menggali hal-hal penting dan menarik untuk diungkapkan dalam penelitian ini sehubungan dengan pengelolaan keuangan daerah dari proses perencanaan dan penganggaran, dan proses pelaksanaan yang mengacu pada Peraturan Menteri Dalam Negeri Nomor 13 Tahun 2006 tentang Pedoman Pengelolaan Keuangan Daerah. Selain itu memudahkan dalam menjaring informasi yang menjadi fokus penelitian. Jawaban dari informan tidak dibatasi oleh penulis sesuai dengan pengetahuan dan pemahamannya mengenai pengelolaan keuangan daerah. Wawancara dilakukan dengan menggunakan jenis In-depth interview dengan metode semi standar atau semi terstruktur dengan durasi waktu 30-60 menit.

b). Dokumentasi.

Menurut Ibrahim (2015:93) dokumen atau dokumentasi dalam penelitian mempunyai 2 (dua) makna yang pertama dokumen yang dimaksudkan sebagai alat bukti tentang sesuatu, termasuk catatan-catatan, foto, rekaman video atau apapun yang dihasilkan oleh penulis. Kedua dokumen yang berkenaan dengan peristiwa atau momen atau kegiatan yang telah lalu, yang padanya mungkin dihasilkan sebuah informasi, fakta dan data yang diinginkan dalam penelitian.

Dokumen dalam penelitian ini adalah : (1) Rencana Pembangunan Jangka Menengah Daerah (RPJMD) Tahun 2014-2019, (2) Rencana Kerja Perangkat Daerah (RKPD) Tahun 2015, (3) Anggaran Pendapatan dan Belanja Daerah (APBD) Tahun 2015, (4). Laporan realisasi Tahun 2015.

\section{Analisis Hasil dan Pembahasan}

Berdasarkan hasil penulisan yang diperoleh dari wawancara dan studi dokumentasi, selanjutnya dilakukan interpretasi atas temuan yang ada sesuai dengan dengan teori/konsep yang mendukung hasil penulisan. Adapun analisis terhadap hasil penulisan dan pembahasan dapat diuraikan sebagai berikut:

I. Analisis Kesesuaian Pengelolaan Keuangan Daerah Pemerintah Kabupaten Kepulauan Talaud Dengan Peraturan Menteri Dalam Negeri Nomor 13 Tahun 2006 tentang Pedoman Pengelolaan Keuangan Daerah.

\section{Proses Perencanaan dan Penganggaran}

1.1 Perencanaan dan penganggaran sesuai dengan Peraturan Menteri Dalam Negeri Nomor 13 Tahun 2006 tentang pedoman pengelolaan keuangan daerah

Perencanaan dan penganggaran merupakan bagian dari proses penentuan kebijakan dalam rangka penyelenggaraan pemerintahan dan pembangunan, sehingga salah satu keluaran dari perencanaan adalah penganggaran. Pengelolaan keuangan daerah Pemerintah Daerah Kabupaten Kepulauan Talaud memang telah mengikuti prosedur yang ada dalam Peraturan Menteri Dalam Negeri Nomor 13 Tahun 2006 tentang Pedoman Pengelolaan Keuangan Daerah dari proses perencanaan dan penganggaran tetapi pelaksanaannya belum optimal, dalam proses perencanaan dan penganggaran Anggaran Pendapatan dan Belanja Daerah (APBD) sebagaimana yang termuat dalam Pasal 81 ayat 1 (satu) untuk menyusun Anggaran Pendapatan dan Belanja Daerah (APBD), Pemerintah Daerah menyusun Rencana Kerja Perangkat Daerah (RKPD) yang merupakan penjabaran dari Rencana Pembangunan Jangka Menengah Daerah (RPJMD) dengan menggunakan bahan dari Rencan Kerja Satuan Kerja Perangkat Daerah (Renja SKPD) untuk jangka waktu 1 (satu) tahun yang mengacu pada Rencana 
Kerja Pemerintah (RKP), pada pasal 81 ayat 2 (dua) Rencana Kerja Pemerintah Daerah (RKPD) yang memuat rancangan kerangka ekonomi daerah, prioritas pembangunan dan kewajiban daerah, rencana kerja yang terukur dan pendanaannya, baik yang dilaksanakan langsung oleh pemerintah, Pemerintah Daerah maupun ditempuh dengan mendorong partisipasi masyarakat. Rencana Kerja Pemerintah Daerah (RKPD) yang telah disusun dijabarkan ke dalam Kebijakan Umum Anggaran (KUA), Prioritas Plafon Anggaran Sementara (PPAS) dan Rencana Kerja Anggaran (RKA) selanjutnya dibahas dan ditetapkan menjadi Anggaran Pendapatan dan Belanja Daerah (APBD) dan Dokumen Pelaksanaan Anggaran (DPA)

\subsection{Musrenbang}

Berdasarkan Peraturan Menteri Dalam Negeri Nomor 54 Tahun 2010 tentang pelaksanaan peraturan pemerintah Nomor 8 Tahun 2008 tentang tahapan, tatacara penyusunan, pengendalian dan evaluasi pelaksanaan rencana pembangunan daerah pasal 117 pelaksanaan musrenbang RKPD sebagaimana dimaksud terdiri dari pelaksanaan musrenbang RKPD provinsi, pelaksanaan musrenbang RKPD kabupaten/kota dan pelaksanaan musrenbang RKPD kabupaten/kota di kecamatan dan merupakan suatu keharusan untuk dilaksanakan dalam tahapan perencanaan tetapi sebagian masyarakat menganggap bahwa musrenbang hanya sebatas formalitas pemerintah daerah dalam hal ini harus mampu menyakinkan masyarakat bahwa musrenbang adalah proses yang harus dilalui berdasarkan Peraturan Menteri Dalam Negeri Nomor 54 Tahun 2010.

\subsection{Pengesahan Renstra dan Renja SKPD}

Berdasarkan Peraturan Menteri Dalam Negeri Nomor 54 Tahun 2010 tentang Pelaksanaan Peraturan Pemerintah Nomor 8 Tahun 2008 tentang Tahapan, Tata Cara Penyusunan, Pengendalian dan Evaluasi Pelaksanaan Rencana Pembangunan Daerah Pasal 97 ayat 5 pengesahan Renstra ditetapkan dengan Keputusan Kepala Daerah ayat 6 berdasarkan Keputusan Kepala Daerah tentang pengesahan Renstra SKPD, Kepala SKPD menetapkan Renstra SKPD menjadi Pedoman unit kerja dilingkungan SKPD dalam menyusun Rancangan Renja SKPD, Pasal 154 ayat 4 Rancangan Renja SKPD Kab/Kota sebagaimana dimaksud dalam pasal 152 ayat 4 ditetapkan dengan keputusan Bupati sedangkan menurut Peraturan Pemerintah Nomor 8 Tahun 2008 tentang Tahapan, Tata Cara Penyusunan, Pengendalian dan Evaluasi Pelaksanaan Rencana Pembangunan Daerah Pasal 26 mengatakan Renstra-SKPD ditetapkan dengan Keputusan Kepala SKPD sedangkan Pasal 28 Renja SKPD ditetapkan dengan Keputusan Kepala SKPD, Renstra dan Renja Pemerintah Kabupaten Kepulauan Talaud hanya disahkan oleh Kepala SKPD, hubungannya dengan penelitian Renstra SKPD dan Renja SKPD seharusnya sudah ditetapkan berdasarkan keputusan bupati sesuai dengan ketentuan peraturan perundang-undangan.

\subsection{Alur Penyusunan RKA-SKPD sampai DPA-SKPD}

Berdasarkan Peraturan Menteri Dalam Negeri Nomor 13 Tahun 2006 tentang Pedoman Pengelolaan Keuangan Daerah Pemerintah Daerah dalam hal ini Satuan Kerja Perangkat Daerah (SKPD) dilaksanakan sesuai alur penyusunan Rencana Kerja Anggaran Satuan Kerja Perangkat Daerah (RKA-SKPD) sampai pada Dokumen Pelaksana Anggaran Satuan Kerja Perangkat Daerah (DPA-SKPD) walaupun belum optimal pelaksanaannya.

\subsection{Kesesuaian Dokumen Perencanaan dengan Prioritas Daerah}

Peraturan Menteri Dalam Negeri Nomor 13 Tahun 2006 tentang Pedoman Pengelolaan Keuangan Daerah Pasal 84 ayat 1 program-program yang tercantum dalam Kebijakan Umum Anggaran (KUA) diselaraskan dengan prioritas pembangunan yang ditetapkan pemerintah Pasal 2 program-program sebagaimana dimaksud diselaraskan dengan prioritas pembangunan yang ditetapkan oleh pemerintah.

\subsection{Sinkronisasi dan Konsistensi Perencanaan dan Penganggaran}

Amanat sinkronisasi sesuai dengan UU Nomor 25 Tahun 2004 tentang Sistem Perencanaan Pembangunan Nasional yaitu untuk mewujudkan keterpaduan dan sinergi pembangunan antar dinas dan antar instansi dan daerah, keterpaduan antara perencanaan dan penganggaran serta untuk mengoptimalkan pemanfaatan partisipasi masyarakat dalam penyusunan perencanaan sedangkan menurut Peraturan Menteri Dalam Negeri Nomor 13 Tahun 2006 tentang Pedoman Pengelolaan Keuangan Daerah pasal 82 ayat 1 (satu) Rencana Kerja Perangkat Daerah (RKPD) disusun untuk menjamin keterkaitan dan konsistensi antara perencanaan, penganggaran, pelaksanaan dan pengawasan.

\subsection{Tim Asistensi}

Berdasarkan Peraturan Menteri dalam Negeri Nomor 13 Tahun 2006 asistensi atau verifikasi dilakukan 4 Badan/Dinas yang masuk dalam Tim Anggaran Pemerintah Daerah (TAPD) dengan 
memverifikasi kesesuaian program/kegiatan dengan Kebijakan Umum Anggaran (KUA) dan Prioritas Plafon Anggaran Sementara (PPAS) dengan ketentuan-ketentuan yang terdapat dalam pedoman penyusunan RKA-SKPD (juknis) tahun berjalan. Pemerintah Kabupaten Kepulauan Talaud dalam tim asistensi masih lemah yang dilaksanakan oleh 4 badan/dinas yang masuk dalam Tim Anggaran Pemerintah Daerah (TAPD) sehingga diperlukan perbaikan mekanisme untuk kedepannya dilaksanakan sesuai dengan tugas dan tanggungjawab masing-masing Satuan Kerja Perangkat Daerah (SKPD) yang terkait dalam Tim Anggaran Pemerintah Daerah (TAPD).

\subsection{Peran Tim Anggaran Pemerintah Daerah (TAPD)}

Tim Anggaran Pemerintah Daerah (TAPD) tim yang dibentuk dengan keputusan Kepala Daerah dan dipimpin oleh Sekretaris Daerah yang mempunyai tugas menyiapkan serta melaksanakan kebijakan kepala daerah dalam rangka penyusunan Anggaran Pendapatan dan Belanja Daerah (APBD) yang anggotanya terdiri dari Pejabat Perencana daerah, Pejabat Pengelola Keuangan Daerah (PPKD) dan Pejabat lainnya sesuai dengan kebutuhan Peraturan Pemerintah Nomr 58 Tahun 2005 Pengelolaan Keuangan Daerah dan Peraturan Menteri Dalam Negeri Nomor 13 Tahun 2006 sebagaimana diubah terakhir dengan Peraturan Menteri Dalam Negeri Nomor 21 Tahun 2011 peranan Tim Anggaran Pemerintah Daerah (TAPD) sangat strategis karena membantu kepala daerah menyusun kebijakan dan mengkoordinasikan penyelenggaraan urusan pemerintahan daerah termasuk pengelolaan keuangan daerah. Khususnya dalam perencanaan dan penganggaran, Tim Anggaran Pemerintah Daerah (TAPD) melakukan penyusunan anggaran berdasarkan ketentuan perundang-undangan. Perencanaan dan penganggaran merupakan proses terintegrasi, olehnya karena output nya dari perencanaan adalah penganggaran (Bastian 2009:10)

\subsection{Penetapan Anggaran Pendapatan dan Belanja Daerah (APBD)}

Peraturan Menteri Dalam Negeri Nomor 13 Tahun 2006 tentang Pedoman Pengelolaan Keuangan Daerah menyebutkan bahwa Anggaran Pendapatan dan Belanja Daerah (APBD) merupakan dasar pengelolaan keuangan daerah dalam masa 1 tahun anggaran dan ditetapkan paling lama 1 bulan sebelum tahun anggaran yang bersangkutan dilaksanakan. Batas waktu penetapan Anggaran Pendapatan dan Belanja Daerah (APBD) seharusnya menjadi acuan bagi daerah dalam proses penyusunan Anggaran Pendapatan dan Belanja Daerah (APBD), namun yang terjadi seringkali pemerintah daerah menetapkan Anggaran Pendapatan dan Belanja Daerah (APBD) nya melampaui batas waktu yang telah ditetapkan.

\subsection{Peran Dewan Perwakilan Rakyat Daerah (DPRD)}

Berdasarkan Undang-Undang Nomor 32 Tahun 2004 Pasal 1 (satu) Dewan Perwakilan Rakyat Daerah (DPRD) mempunyai legislatif, anggaran dan pengawasan. Adapun fungsi legislatif yang dimaksud untuk membentuk peraturan daerah bersama kepala daerah, fungsi anggaran bersama-sama dengan pemerintah daerah menyusun dan menetapkan Anggaran Pendapatan dan Belanja Daerah (APBD) yang di dalamnnya termasuk anggaran untuk pelaksanaan fungsi, tugas dan wewenang Dewan Perwakilan Rakyat Daerah (DPRD) sedangkan fungsi pengawasan untuk melakukan pengawasan terhadap pelaksanaan undang-undang peraturan daerah dan keputusan kepala daerah serta kebijakan yang ditetapkan oleh pemerintah daerah.

\subsection{Meraih Penghargaan Terbaik Pangripta Nusantara}

Berdasarkan salinan keputusan Menteri Perencanaan Pembangunan Nasional/Kepala Badan Perencanaan Pembangunan Nasional Nomor KEP 60/M.PPN/HK/04/2013 tentang Pemberian Anugerah perencanan terbaik "Pangripta Nusantara" tingkat Kabupaten/Kota Tahun 2013 tanggal 26 April 2013 mendapat terbaik II dan pada Tahun 2016 mendapatkan peringkat ke III dan tentunya hal ini mungkin bisa berpengaruh kepada pembangunan daerah. Dalam hubungannya dengan penelitian ini adalah bagaimana Perencanaan itu harus ada keterkaitan, konsistensi, kelengkapan dan kedalaman, keterukuran, inovasi kebijakan, proses perencanaan dari bawah (bottom up), proses perencanaan dari atas (top down), proses perencanaan teknokratik, proses perencanaan politik, inovasi proses dan program daerah Pembangunan di Pemerintah Kabupaten Kepulauan Talaud sehingga bisa mempertahankan penghargaan yang telah diraih

\subsection{E-Planning}

Berdasarkan Peraturan Menteri Dalam Negeri Nomor 54 Tahun 2010 tentang Tahapan, Tata Cara Penyusunan, Pengendalian dan Evaluasi Pelaksanaan Rencana Pembangunan Daerah penerapan aplikasi E-Planning dalam perencanaan pembangunan daerah sudah harus dilaksanakan untuk mendorong partisipasi masyarakat demi terwujudnya sistem pemerintahan yang transparan, partisipasif, responsif, efisien dan akuntabel tetapi pemerintah kabupaten kepuluan talaud sendiri 
belum menerapkan E-Planning. Peran E-Planning merupakan peluang bagi pengaksesan, pengelolaan dan pendayagunaan informasi secara cepat dan akurat sesuai dengan skala prioritas kebutuhan pembangunan suatu daerah, kondisi ini sangat bermanfaat dalam pencapaian efisiensi dan efektifitas kinerja aparatur penyelenggara pemerintahan serta merupakan fasilitas tersendiri bagi pemerintah dalam berinteraksi dengan berbagai pemangku kepentingan (stakeholders) yang pada akhirnya akan memicu transformasi paradigma penyelenggaraan pemerintahan daerah pada berbagai tingkatan pengambilan keputusan.

\section{Proses Pelaksanaan}

Peraturan Pemerintah Nomor 58 Tahun 2005 tentang Pengelolaan Keuangan Daerah dan Peraturan Menteri Dalam Negeri Nomor 13 Tahun 2006 tentang Pedoman Pengelolaan Keuangan Daerah, Peraturan Menteri Dalam Negeri Nomor 59 Tahun 2007 tentang Perubahan Atas Peraturan Menteri Dalam Negeri Nomor 13 Tahun 2006 tentang Pedoman Pengelolaan Keuangan Daerah, lingkup pelaksanaan keuangan daerah mencakup 2 kegiatan yaitu mulai dari penyusunan Dokumen Pelaksanaan Anggaran Satuan Kerja Perangkat Daerah (DPA-SKPD) dan Dokumen Pelaksanaan Anggaran Pejabat Pengelola Keuangan Daerah (DPA-PPKD) serta penyusunan anggaran kas.

Dalam pelaksanaan Anggaran Pendapatan dan Belanja Daerah (APBD) baik atas pelaksanaan penerimaan maupun pengeluaran daerah, pihak-pihak yang terlibat di dalamnya harus taat pada azas umum pelaksanaan Anggaran Pendapatan dan Belanja Daerah (APBD) yang di atur dalam peraturan perundang-undangan yaitu:

1. Semua penerimaan daerah dan pengeluaran daerah dikelola dalam Anggaran Pendapatan dan Belanja Daerah (APBD) yang artinya tidak boleh ada penerimaan yang dikelola di luar Anggaran Pendapatan dan Belanja Daerah (APBD).

2. Setiap Satuan Kerja Perangkat Daerah (SKPD) yang mempunyai tugas memungut dan/atau menerima pendapatan daerah wajib melaksanakan pemungutan dan/atau penerimaan berdasarkan ketentuan yang ditetapkan dalam peraturan perundang-undangan sehingga pemungutan dan/atau penerimaan daerah tidak menjadi beban hanya satu Satuan Kerja Perangkat Daerah (SKPD) saja, menjadi tanggungjawab semua Satuan Kerja Perangkat Daerah (SKPD) yang mempunyai penerimaan berdasarkan peraturan perundang-undangan.

3. Jumlah belanja yang dianggarkan dalam merupakan batas tertinggi untuk setiap pengeluaran belanja, artinya pengeluaran tidak dapat dibebankan pada anggaran belanja jika untuk pengeluaran tersebut tidak tersedia atau tidak cukup tersedia dalam Anggaran Pendapatan dan Belanja Daerah (APBD) dan juga setiap Satuan Kerja Perangkat Daerah (SKPD) dilarang melakukan pengeluaran atas beban anggaran daerah untuk tujuan lain dari yang telah ditetapkan dalam Anggaran Pendapatan dan Belanja Daerah (APBD).

4. Pengeluaran belanja daerah menggunakan prinsip hemat, tidak mewah, efektif, efisien dan sesuai dengan ketentuan peraturan perundang-undangan.

\subsection{Pelaksanaan Sesuai Dengan Peraturan Menteri Dalam Negeri Nomor 13 Tahun 2006} Tentang Pedoman Pengelolaan Keuangan Daerah.

Pemerintah Kabupaten Kepulauan Talaud melaksanakan program/kegiatan disesuaikan dengan Peraturan Menteri Dalam Negeri Nomor 13 Tahun 2006 tentang Pedoman Pengelolaan Keuangan Daerah tetapi pelaksanaannya belum optimal.

\subsection{Alur Pencairan}

Pemerintah Kabupaten Kepulauan Talaud dalam proses pencairan keuangan pejabat yang terkait di dalamnya sudah memahami alur pencairan keuangan pengelolaan keuangan daerah tapi seringkali tidak patuh pada aturan yang ada karena seringkali melewati batas yang ditetapkan.

\subsection{Lama Pencairan}

pejabat pengelola keuangan SKPD sudah memahami implementasi dalam proses pencairan pelaksanaan program/kegiatan yaitu 2 hari lamanya sesuai regulasi yang mengatur Peraturan Menteri Dalam Negeri Nomor 13 Tahun 2006 tentang Pedoman Pengelolaan Keuangan Daerah tetapi terkadang proses pencairan keuangannya bisa lebih dari 2 hari.

\subsection{Anggaran Kas}

Anggaran kas yang di yang digunakan untuk mengatur ketersediaan dana untuk membiayai pengeluaran dalam pelaksanaan adakalanya tidak tepat waktu dalam pelaksanaannya.

\subsection{Keterlambatan pelaksanaan program/kegiatan}


Pelaksanaan pengadaan barang dan jasa yang dikontrakan maupun pelaksanaan program/kegiatan SKPD sering mengalami keterlambatan tapi Pemerintah Kabupaten Kepulauan Talaud berusaha untuk meminimalisir keterlambatan pelaksanaan program/kegiatan tersebut.

\subsection{Penyerapan Anggaran}

Penyerapan anggaran yang ada di Kabupaten Kepulauan Talaud memang sudah melebihi target tapi apakah output dan outcome nya bisa mencapai target atau tidak.

\subsection{Pelaporan Pejabat Pelaksana Teknis Kegiatan (PPTK)}

Pelaporan program/kegiatan merupakan suatu kewajiban yang harus dipenuhi Pejabat Pelaksana Teknis Kegiatan (PPTK) dalam pelaksanaan program/kegiatan ketika Pejabat Pelaksana Teknis Kegiatan (PPTK) tidak menyampaikan atau tidak melaporkan pelaksanaan program/kegiatan maka akan berpengaruh pada pelaksanaan program/kegiatan selanjutnya di Kabupaten Kepulauan Talaud terkadang Pejabat Pelaksana Teknis Kegiatan (PPTK) terkadang lalai atau terlambat dalam menyampaikan laporan pelaksanaan program/kegiatan.

\subsection{Pengawasan/Monitoring Dan Evaluasi}

Pemerintah Kabupaten Kepulauan Talaud melalui Bappeda Kabupaten Kepulauan Talaud sudah melakukan evaluasi per triwulan bahkan semester bahkan DPRD juga sudah melakukan tugas dan fungsinya sebagai wakil dari masyarakat.

\subsection{Manfaat atau dampak Pelaksanaan program/kegiatan}

Pelaksanaan sudah berdampak atau dirasakan masyarakat khususnya pembangunan infrastruktur bahkan lewat dokumen perencanaan sudah sesuai keinginan masyarakat walaupun kadang harus di tunda karena anggaran yang tidak mencukupi.

\section{Hambatan-Hambatan Pengelolaan Keuangan Daerah Dari proses Perencanaan Dan Penganggaran, dan Proses Pelaksanaan \\ 1. Struktur Birokrasi}

Hambatan struktur birokrasi yang dtemukan dalam pengelolaan keuangan daerah pada Pemerintah Kabupaten Kepulauan Talaud yaitu seringkali pagu anggaran di APBD sudah tersedia tapi juknisnya seringkali turun terlambat dari Pemerintah Pusat yang merupakan salah satu hambatan dalam implementasi pengelolaan keuangan daerah.

\section{Sumber Daya}

\subsection{Sumber Daya Manusia}

Hambatan sumber daya manusia di dapat bahwa seringkali pegawai yang dibutuhkan tidak berada ditempat. Kemudian karena kurangnya sumber daya manusia yang ada sehingga sumber daya manusia yang ada bisa mengerjakan lebih dari satu suatu pekerjaan, hambatan sumber daya manusia berkaitan dengan Latar belakang pendidikan.

\subsection{Sarana dan Prasarana}

Hambatan sumber daya kedua adalah sarana prasarana kekurangan data dari bagian perencaaan, Sarana prasarana yang tidak memadai karena masalah jaringan internet untuk menerapkan program $E$ Planning yang diamanatkan oleh Pemerintah Pusat.

\subsection{Letak Geografis}

Kabupaten Kepulauan Talaud merupakan suatu daerah kepulauan sehingga letak geografis sangatlah berpengaruh dalam pengelolaan keuangan daerah terutama pada pelaksanaan program kegiatan karena pada bulan tertentu cuaca sangat ekstrim sehingga seringkali menghambat dalm pelaksanaan pekerjaan terutama pekerjaan infrastruktur karena keterlambatan material, faktor cuaca, tempat yang terisolir.

\section{Komunikasi}

Dalam penelitian ditemukan hambatan komunikasi yaitu kurangnya koordinasi antar bidang bahkan antar SKPD. Menurut Edward (1980:9) Implementasi akan berjalan efektif apabila ukuran-ukuran dan tujuan-tujuan kebijakan dipahami oleh individu-individu yang bertanggung jawab dalam pencapaian tujuan kebijakan. Kejelasan ukuran dan tujuan kebijakan dengan demikian perlu dikomunikasikan secara tepat dengan para pelaksana. Konsistensi atau keseragaman dari ukuran dasar dan tujuan perlu dikomunikasikan sehingga implementor mengetahui secara tepat ukuran maupun tujuan kebijakan itu. Komunikasi dalam organisasi merupakan suatu proses yang amat kompleks dan rumit. Sumber informasi yang berbeda dapat melahirkan interpretasi yang berbeda pula. Agar implementasi berjalan efektif, siapa yang bertanggungjawab melaksanakan sebuah keputusan harus mengetahui apakah sebuah implementasi dapat terlaksana. 


\section{Disposisi atau Sikap}

Hambatan Disposisi atau sikap yang ditemukan dalam penelitian ini adalah kebijakan pimpinan, permintaan politik masyarakat karena sesuatu lain hal sehingga mempengaruhi perencanaan penganggaran dan pelaksanaan bahkan proses pembahasan APBD. Pada Pemerintah Daerah Kabupaten Kepulauan Talaud para implementor memiliki sikap atau perspektif yang berbeda dengan pembuat kebijakan, maka proses implementasi kebijakan juga menjadi tidak efektif yang dipengaruhi oleh situasi dan motivasi. Selain itu sejalan dengan pendapat Rondinelli (1981) ASN di Kabupaten Kepulauan Talaud memiliki sikap keengganan untuk melakukan delegasi wewenang. Inilah yang menjadi penghambat dalam pengelolaan keuangan daerah.

\section{Keterbatasan Anggaran}

Menurut Didit Herlianto (2014:1) menyatakan anggaran dapat menyajikan informasi yang jelas mengenai tujuan, sasaran, hasil dan manfaat yang diperoleh dari suatu kegiatan. Karena pada dasarnya anggaran merupakan suatu rencana kerja yang dinyatakan secara kuantitatif dari aktivitas suatu organisasi. Adi Saputro dan Asri dalam Didit Herlianto (2014:2) menyatakan anggaran adalah suatu pendekatan yang formal dan sistematis daripada pelaksanaan tanggungjawab manajemen di dalam perencanaan, koordinasi dan pengawasan. Pada dasarnya anggaran yang bermanfaat dan realistis tidak hanya dapat membantu mempererat kerjasama karyawan, memperjelas kebijakan dan merealisasikan rencana saja. Tetapi juga dapat menciptakan keselarasan yang lebih baik dalam perusahaan keserasian tujuan diantara manajer dan bawahannya.

Perencanaan dan penganggaran bahkan pelaksanaan program/kegiatan harus didukung oleh ketersediaan anggaran. Hal ini dimaksudkan untuk menjamin proses pelaksanaan kegiatan yang bersumber dari APBD efektif, tepat sasaran dan dapat dipertanggungjawabkan. Komitmen manajemen dalam hal ini pimpinan daerah harus disokong oleh ketersediaan anggaran pula.

Dari pernyataan informan dikaitkan dengan teori menyatakan bahwa dalam perencanaan dan penganggaran, dan pelaksanaan program/kegiatan karena adanya keterbatasan anggaran sehingga tidak bisa terealisasi terutama dalam hal penerapan E-Planning, musrenbang ada kegiatan yang tidak bisa dilaksanakan bahkan kesesuaian program dan keterlambatan pelaksanaan program, karena anggaran dapat dipakai sebagai alat pengendalian biaya, hanya apabila semua pihak, terutama manajer-manajer perusahaan, secara terus menerus terkoordinir dan berusaha bertanggungjawab atas tercapainya tujuan yang telah ditentukan di dalam anggaran.

\section{Upaya-Upaya Mengatasi Hambatan-Hambatan Pengelolaan Keuangan Daerah Dari Proses Perencanaan Dan Penganggaran, Dan Proses Pelaksanaan \\ 1. Upaya Mengatasi Hambatan Struktur Birokrasi}

Mengatasi hambatan struktur birokrasi dalam proses perencanaan, penganggaran dan pelaksanaan hal gagal lelang pemerintah menyesuaikan dengan perubahan APBD. Menurut Edward (1980:9) implementasi kebijakan dipengaruhi Struktur organisasi yang bertugas mengimplementasikan kebijakan memiliki pengaruh yang signifikan terhadap implementasi kebijakan. Salah satu dari aspek struktur yang penting dari setiap organisasi adalah adanya prosedur operasi yang standar (standard operating procedures atau SOP). SOP menjadi pedoman bagi setiap implementor dalam bertindak. Struktur organisasi yang terlalu panjang akan cenderung melemahkan pengawasan dan menimbulkan red-tape, yakni prosedur birokrasi yang rumit dan kompleks serta menyebabkan aktivitas organisasi tidak fleksibel.

\section{Upaya Mengatasi Hambatan Sumber Daya}

Mengatasi hambatan sumber daya dalam proses perencanaan dan penganggaran sampai pelaksanaan program/kegiatan Pemerintah Daerah berusaha mengikutsertakan bimtek perencanaan, bimtek simda, meningkatkan pemahaman aturan, pelatihan-pelatihan, meningkatkan kinerja bahkan mempergunakan waktu yang ada. Selain sumber daya manusia dan informasi, sumber daya lain yang juga penting adalah kewenangan untuk menentukan bagaimana kebijakan dilakukan, kewenangan untuk membelanjakan/mengatur keuangan, baik penyediaan uang, pengadaan staf, maupun pengadaan supervisor serta fasilitas-fasilitas yang diperlukan untuk melaksanakan kebijakan seperti kantor dan peralatan.

\section{Upaya Mengatasi Hambatan Komunikasi}

Mengatasi hambatan komunikasi dalam proses perencanaan dan penganggaran, dan pelaksanaan program/kegiatan dengan meningkatkan koordinasi antar bidang, koordinasi dengan kementerian lembaga serta mengevaluasi, Mengatasi hambatan dalam sinkronisasi dan konsisten perencanaan dan penganggaran, dan pelaksanaan dengan melakukan komunikasi dengan masyarakat. Menurut Edward 
(1980:9) Implementasi akan berjalan efektif apabila ukuran-ukuran dan tujuan-tujuan kebijakan dipahami oleh individu-individu yang bertanggung jawab dalam pencapaian tujuan kebijakan. Kejelasan ukuran dan tujuan kebijakan dengan demikian perlu dikomunikasikan secara tepat dengan para pelaksana. Konsistensi atau keseragaman dari ukuran dasar dan tujuan perlu dikomunikasikan sehingga implementor mengetahui secara tepat ukuran maupun tujuan kebijakan itu. Komunikasi dalam organisasi merupakan suatu proses yang amat kompleks dan rumit. Sumber informasi yang berbeda dapat melahirkan interpretasi yang berbeda pula. Agar implementasi berjalan efektif, siapa yang bertanggungjawab melaksanakan sebuah keputusan harus mengetahui apakah sebuah implementasi dapat terlaksana.

\section{Upaya Mengatasi Hambatan Disposisi atau Sikap}

Mengatasi hambatan disposisi atau sikap dengan mengusulkan tambahan beban kerja, komitmen pemerintah dengan legislatif, konsistensi penempatan pegawai, pengawasan bahkan pembinaan. Salah satu variabel yang mempengaruhi implementasi kebijakan menurut teori Edward III (1980) adalah sikap atau disposisi implementor. Disposisi adalah watak atau karakteristik yang dimiliki oleh implementor, seperti komitmen, kejujuran dan sifat demokrasi. Jika implementor setuju dengan isi dari kebijakan maka mereka akan melaksanakan dengan senang hati, tetapi jika pandangan mereka berbeda dengan pembuat kebijakan, maka proses penerapan akan mengalami banyak masalah. Salah satu faktor yang mempengaruhi efektivitas implementasi kebijakan adalah sikap implementor. Apabila implementor memiliki disposisi yang baik, maka sebuah kebijakan akan dapat dijalankan dengan baik seperti apa yang diinginkan oleh pembuat kebijakan. Oleh karena itu Dennis A.Rondinelli (1981) pernah mengingatkan bahwa penyebab kegagalan utama dalam melaksanakan orientasi pelayanan publik ini salah satunya adalah adanya sikap keengganan untuk melakukan delegasi wewenang.

\section{Upaya Mengatasi Hambatan Keterbatasan Anggaran.}

Mengatasi hambatan keterbatasan anggaran dengan menyediakan anggaran, Walau terdapat manfaat yang diperoleh dengan penyusunan anggaran, tetapi masih terdapat keterbatasan-keterbatasan anggaran. Keterbatasan anggaran menurut Supriyono dalam Didit Herlianto (2015:9) adalah sebagai berikut:

1. Anggaran didasarkan pada estimasi atau proyeksi atas kegiatan yang akan datang, ketepatan dari estimasi sangat tergantung kepada pengalaman dan kemampuan dari estimator atau proyektor, ketidaktepatan anggaran berakibat tidak dapat dipakai sebagai alat perencanaan, koordinasi dan pengawasan baik.

2. Anggaran harus selalu disesuaikan dengan perubahan kondisi dan asumsi. Anggaran disusun atas dasar kondisi dan asumsi yang mendasari penyusunan anggaran mengharuskan adanya revisi anggaran, agar anggaran tersebut dapat digunakan sebagai alat pengendalian. Perubahan kondisi dan asumsi misalnya dapat berupa: laju inflasi atau kebijakan pemerintah dibidang ekonomi.

3. Anggaran dapat dipakai sebagai alat pengendalian biaya, hanya apabila semua pihak, terutama manajer-manajer perusahaan, secara terus menerus terkoordinir dan berusaha bertanggungjawab atas tercapainya tujuan yang telah ditentukan di dalam anggaran.

4. Semua pihak di dalam perusahaan perlu menyadari bahwa anggaran adalah alat untuk mengendalikan biaya, akan tetapi tidak dapat menggantikan fungsi manajemen dan judgement manajemen masih diperlukan atas dasar pengetahuan dan pengalamannya.

Dari pernyataan informan dikaitkan dengan teori menyatakan bahwa dalam perencanaan, penganggaran dan pelaksanaan program/kegiatan karena adanya keterbatasan anggaran sehingga tidak bisa terealisasi terutama dalam hal penerapan E-Planning, musrenbang ada kegiatan yang tidak bisa dilaksanakan bahkan kesesuian program dan keterlambatan pelaksanaan program. Anggaran dapat dipakai sebagai alat pengendalian biaya, hanya apabila semua pihak, terutama manajer-manajer perusahaan, secara terus menerus terkoordinir dan berusaha bertanggungjawab atas tercapainya tujuan yang telah ditentukan di dalam anggaran.

\section{Kesimpulan}

Dari hasil analisis dan pembahasan dalam pengelolaan keuangan daerah Pemerintah Daerah Kabupaten Kepulauan Talaud berdasarkan Peraturan Menteri Dalam Negeri Nomor 13 Tahun 2006 tentang Pedoman Pengelolaan Keuangan Daerah dapat disimpulkan Pengelolaan keuangan daerah Pemerintah Daerah Kabupaten Kepulauan Talaud dari proses perencanaan dan penganggaran dan pelaksanaan dapat disimpulkan bahwa:1) Proses perencanaan dan penganggaran berdasarkan ketentuan dalam Peraturan Menteri Dalam Negeri nomor 13 Tahun 2006 tentang pedoman 
pengelolaan keuangan daerah untuk menjamin keterkaitan dan konsistensi antara perencanaan dan penganggaran tetapi pada Pemerintah Kabupaten Kepulauan Talaud selama ini sebagian tidak sinkron. 2)Proses Pelaksanaan Pemerintah Kabupaten Kepulauan Talaud dalam proses pencairan keuangan pejabat yang terkait di dalamnya sudah memahami alur pencairan keuangan pengelolaan keuangan daerah tapi seringkali tidak patuh pada aturan yang ada karena seringkali melewati batas yang ditetapkan.

Dalam proses perencanaan dan penganggaran, dan proses pelaksanaan ditemukan beberapa hambatan sebagai berikut: 1) Struktur Birokrasi dalam pelaksanaan dana alokasi khusus seringkali juknis dari pemerintah pusat turun terlambat yang mengakibatkan tidak teralisasinya dana alokasi khusus. 2)Sumber daya: sumber daya manusia masih kurangnya sumber daya manusia sehingga terjadinya rangkap pekerjaan, kualitas sumber daya manusia yang mengakibatkan salah penganggaran kemudian penempatan sumber daya manusia tidak sesuai dengan latar belakang pendidikan, sarana prasarana: bagi SKPD perencana Bappelitbang kekurangan data dalam penyusunan dokumen perencanaan, belum diterapkannya E-Planning karena masalah jaringan internet, letak geografis: faktor cuaca, daerah yang terisolir yang mengakibatkan keterlambatan pelaksanaan pekerjaaan, 3)Komunikasi: kurangnya koordinasi antar bidang/SKPD bahkan antar Kementerian/Lembaga terutama dalam penyusunan dokumen perencanaan.4)Disposisi atau Sikap: kebijakan pimpinan, permintaan politik masyarakat mempengaruhi perencanaan, penganggaran dan pelaksanaan dalam pengelolaan keuangan daerah. 5)Keterbatasan Anggaran: pelaksanaan kegiatan yang tidak dilaksanakan karena dana yang tersedia dalam hal penerapan E-Planning, pelaksanaan musrenbang bahkan kesesuaian program maupun keterlambatan pelaksanaan program/kegiatan semua karena keterbatasan anggaran.

Dalam mengatasi hambatan-hambatan maka upaya-upaya yang dilakukan Pemerintah Daerah dalam proses perencanaan dan penganggaran, dan pelaksanan adalah sebagai berikut: 1) Struktur Birokrasi: proses perencanaan, penganggaran dan pelaksanaan gagal lelang menyesuaikan dengan perubahan APBD. 2) Sumber daya: sumber daya manusia, mengikutsertakan bimtek perencanaan, bimtek simda, meningkatkan pemahaman aturan, pelatihan-pelatihan, meningkatkan kinerja bahkan mempergunakan waktu yang ada. 3) Komunikasi: meningkatkan koordinasi antar bidang, antar kementerian/lembaga serta mengevalusi. 4) Disposisi atau Sikap: mengusulkan tambahan beban kerja, komitmen pemerintah dengan legislatif, konsistensi penempatan pegawai, pengawasan dan pembinaan. 5) Keterbatasan Anggaran: menyediakan anggaran untuk mengikutsertakan bimtek.

\section{Saran}

Ada beberapa hal yang dapat disarankan dan menjadi perhatian bagi Pemerintah Kabupaten Kepulauan Talaud mulai proses perencanaan, penganggaran dan pelaksanana dalam pengelolaan keuangan daerah antara lain:

1. Pemerintah Kabupaten Kepulauan Talaud dalam proses perencanaan, penganggaran dan pelaksanaan dalam hal proses pelelangan harus dilakukan lebih awal sehingga proses pelaksanaannya tidak akan terlambat.

2. Perlunya adanya peningkatan kapasitas SDM kepada ASN sebagai melalui Bimtek perencanaan, bimtek simda, pelatihan-pelatihan untuk meningkatkan kinerja.

3. Pemerintah Daerah harus lebih meningkatkan koordinasi antar bidang/SKPD bahkan meningkatkan koordinasi kementerian/lembaga terkait.

4. Pemerintah daerah harus meningkatkan kesejahteraan pegawai dalam rangka pelaksanaan tugas dan tanggungjawab, harus mempunya komitmen yang kuat antara pemerintah paerah dengan legislatif, penempatan konsistensi pegawai sesuai dengan latar belakang pendidikan bahkan melakukan pengawasan dan pembinaan terhadap ASN yang ada.

5. Menyediakan anggaran dalam pelaksanaan bimtek perencanaan, bimtek simda.

\section{DAFTAR PUSTAKA}

Arikunto, Suharsimi. 2010. Prosedur Penelitian: Suatu Pendekatan Praktik. Rineka Cipta. Jakarta.

BPKP. 2011 Badan Pengawasan Keuangan dan Pembangunan

BPKP. 2012 Badan Pengawasan Keuangan dan Pembangunan

Herlianto Didit. (2014). Anggaran Keuangan. Cetakan pertama. Gosyen Publishing Yogyakarta.

Edwards, George C. III..1980. "Implementing Public Policy". Washington DC: Congresional, Quartely Press. 
Ibrahim. 2015. Metodologi Penelitian Kualitatif: Panduan Penelitian beserta Contoh Proposal Kualitatif. Perpustakaan Nasional: Katalog dalam Terbitan. Pontianak.

Keputusan Menteri Perencanaan Pembangunan Nasional/Kepala Badan Perencanaan Pembangunan Nasional Nomor Kep.60/M.PPN/PH/04/2013 tentang Pemberian Anugerah Perencanaan Terbaik" Pangripta Nusantara" Tingkat Kabupaten/Kota Tahun 2013.

Mulyana, Budi, 2010. Modul Perencanaan dan Penganggaran Daerah Kementerian Keuangan Republik Indonesia Badan Pendidikan dan Pelatihan Keuangan, Jakarta.

Republik Indonesia. Undang-Undang No. 17 Tahun 2003 tentang Keuangan Negara. Jakarta.

Republik Indonesia. Undang-Undang Nomor 25 Tahun 2004 tentang Sistem Perencanaan Pembangunan Nasional. Jakarta.

Republik Indonesia. Undang-Undang No. 32 Tahun 2004 tentang Pemerintahan Daerah. Jakarta.

Republik Indonesia. Peraturan Pemerintah No. 58 Tahun 2005 Tentang Pengelolaan Keuangan Daerah. Perubahan Atas Peraturan Menteri Dalam Negeri No. 13 Tahun 2006 Tentang Pedoman Pengelolaan Keuangan Daerah. Jakarta.

Republik Indonesia. Permendagri Nomor 13 tahun 2006 tentang Pedoman Pengelolaan Keuangan Daerah. Jakarta.

Republik Indonesia. Permendagri Nomor 59 tahun 2007 tentang Perubahan Pertama atas Permendagri Nomor 13 tahun 2006 tentang Pedoman Pengelolaan Keuangan Daerah. Jakarta.

Republik Indonesia. Peraturan Pemerintah No. 8 Tahun 2006 Tentang Pelaporan Keuangan dan Penilaian Kinerja.

Republik Indonesia. Permendagri Nomor 21 tahun 2011 tentang Perubahan Kedua atas Permendagri Nomor 13 tahun 2006 tentang Pedoman Pengelolaan Keuangan Daerah. Jakarta.

Republik Indonesia. Permendagri Nomor 54 tahun 2010 tentang pelaksanaan peraturan pemerintah Nomor 8 Tahun 2008 tentang tahapan, tatacara penyusunan, pengendalian dan evaluasi pelaksanaan rencana pembangunan

Rondinelli, Dennis A. 1981. Government Decentralization in Comparative Perspective Theory and Practice in Developing Countries: International Review of Administrative Sciences.

Sugiyono. 2014-2015. Metode Penelitian Kuantitatif, Kualitatif, dan Kombinasi (Mixed Methods). Bandung: Alfabeta. 